Among the most interesting exhibits were a number of preparations by Dr. Albert Gray and Dr. Kerr Love.

Great regret was felt that the serious illness of Professor NcKendrick prevented him from giving the demonstration of experiments illustrating recent researches on the physical nature of rowel tones and their bearing on the movements of the tympanic nembrane. Dr. Colquhoun succeeded in interesting and instructing the Society by his admirable exposition and experimentation, but no one could reproduce the Professor's enthusiastic joy in the demonstration of material which his old students knew him to have so much at heart, and to which Dr. Colquhoun most feelingly referred. The demonstration refreshed the memory of the hearers with regard to much they had formerly learned, and brought them well up to the present state of knowledge of the subject.

The hospitality exercised by the President was greatly enjoyed, and gare point to Professor Urban Pritchard's post-prandial suggestion that the laws of the Society should be altered in order to admit of Dr. Barr being made Perpetual President.

\title{
THE FIFTEENTH INTERNATIONAL CONGRESS OF MEDICINE, LISBON, APRIL, 1906.
}

WE have received the first number of the Journal of the Fifteenth International Congress of Medicine, to be held in Lisbon from April 19 to 26, 1906. This number contains the regulations of the Congress, the organisation of the sections and of the different national committees. Under the second article of the regulations, besides doctors, only scientists introduced by the national or Portuguese committees can be admitted to the Congress.

The subscription is 25 francs or 20 marks or one pound sterling. The work of the Congress is distributed in 17 sections as follows:

1-Anatomy (Descriptive and Comparative Anatomy, Anthropology, Embryology, Histology).

2-Physiology.

3-General Pathology, Bacteriology, and Pathological Anatomy.

4-Therapeutics and Pharmacology.

5-Medicine.

6 -Pediatrics.

7-Neurology, Psychology, and Criminal Anthropology

8-Dermatology and Syphilography.

9-Surgery.

10-Medicine and Surgery of the Urinary Organs.

11-Ophthalmology. 
12-Laryngology, Rhinology, Otology, and Stomatology.

13-Obstetrics and Grnæcologv.

14-Hygiene and Epidemiology.

15-Military Medicine.

16-Legal iredicine.

17-Eolonial and Naval Medicine.

The Fxecutive Committee of the Congress will print, before the Cungress opens, all the official reports; it is therefore necessaly that they should be forwarded before September 30, 1905, to the General Secretary. Other communications should be forwarderl before December 31, 1905, if the authors desire their conclusions printed before the opening of the Congress.

The official language is French. In the general assemblies, in well as in the sections, English, German, and French may be usenl. We note that the Committee of the Congress has excluded the Portuguese from the official languages; this has obviously been done with the intention of diminishing the number of languages.

The President of the Committee of Organisation is Dr. M. dit Costa Alemao; the General Secretary is Dr. Miguel Bombardia; all adhesions must be addressed to the latter at the Hospital de Rilhafolles, Lisbon.

The following gentlemen form the Committee of Section 12. Laryngology, Rhinology, Otology and Stomatology :

Président-M. Gregorio Fernandes. Secretaries-M. Avelinn Monteiro, M. Caldeira Cabral. Membrex-MM. Amor de Mellu, Manoel Valladares, Manuel Caroça, Sant'Amna Leite.

\title{
A CASE OF DEAFNESS FOLLOWING ON NASAL OBSTRUCTION WITHOUT OTHER DISEASE OF THE HEARING APPARATUS.
}

\author{
By Dr. Wallace Mackenzie, Wellington, N.Z.
}

A. P-WAs under my treatment in the out-patient department of the Wellington District Hospital during February, 1897, on accoulit of deafness in both ears.

His father died of cancer of the larynx at about fifty-seven years of age, otherwise his family history was good. The patient was a strong, healthy man twenty-four years of age. Five month. previously he had had his nose treated with the galvano-cautery because he had a difficulty in breathing through it when he had : cold. After the treatment the nasal obstruction became almost 